\title{
Pengaruh Systemic Lupus Eritematosus (Sle) Terhadap Kadar Albumin Urin dan Tekanan Darah Pada Mencit Balb/C Model Lupus Bunting
}

Aminah Maya

STIKes Muhammadiyah Palembang

\section{Informasi Artikel :}

Diterima : 20 Maret 2020

Diperbaiki : 27 Maret 2020

Disetujui : 05 April 2020

"Korespondensi Penulis: mayachabie@gmail.com

\section{A B S T R A K}

Kehamilan dengan LES merupakan kehamilan berisiko tinggi karena dapat membahayakan ibu dan bayi yang dikandungnya. Sekitar $75 \%$ kehamilan mencapai masa kelahiran, walaupun $25 \%$ diantaranya prematur dan $25 \%$ sisanya mengalami keguguran. Beberapa komplikasi yang bisa terjadi pada kehamilan yaitu kematian janin, hipertensi dan kelainan ginjal, mortalitas janin ,pertumbuhan janin terhambat, Sindroma Lupus Eritematosus Neonatal (LEN) yang dapat menyebabkan blok jantung kongenital, lesi kutaneus sesaat, kelainan hepar dan berbagai manifestasi sistemik lainnya pada neonatus yang lahir dari seorang ibu uang menderita LES pada saat hamil. Tujuan penelitian ini untuk mengetahui pengaruh SLE terhadap kadar albumin urin dan tekanan darah mencit BALB/c Model Lupus Bunting. Penelitian ini merupakan penelitian true eksperimen dengan pendekatan post test only control group design, dilaksanakan di Laboratorium Fakultas Kedokteran Universitas Brawijaya. Variabel bebas dalam penelitian ini adalah Kejadian Systemic Lupus Eritemathosus (SLE) pada mencit dan variabel terikat adalah tekanan darah mencit BALB/c yang diukur pada hari ke 14 gestasi menggunakan CODA Non Invasive Blood Pressure System Owner's Manual for CODA Monitor dan Kadar albumin urin yang diukur dengan menggunakan Mouse ALB (Albumin) ELISA Kit (Cat No. E-EL-M0656) pada hari ke-14 gestasi. Analisis data dalam penelitian ini menggunakan analisis univariat dan analisis bivariat dengan menggunakan Independen $t$ test. Dari hasil uji statistik, pengaruh kejadian SLE terhadap kadar albumin urin, diperoleh tingkat signifikansi $\rho<0.05$ ( $\rho: 0.005)$ dan untuk pengaruh kejadian SLE terhadap tekanan darah diperoleh tingkat signifikansi $\rho<0.05$ ( $\rho$ : 0.004) sehingga dapat disimpulkan bahwa ada pengaruh yang signifikan antara kejadian SLE terhadap kadar albumin urin dan tekanan darah pada mencit BALB/c model lupus bunting. Mencit BALB/c model Lupus Bunting memiliki Kadar Albumin Urin dan Tekanan darah dan lebih tinggi dari pada mencit bunting normal.

\section{Kata Kunci : Kejadian SLE, Kadar Albumin Urin, Tekanan Darah}


approach post test only control group design, carried out in the laboratory of the Brawijaya University. Independent Variable of the research is the incidence of the systemic lupus eritemathosus ( $S L E$ ) in mice and dependent variable is blood pressure that was measured on day 14 of gestation use coda non invasive blood pressure system manual for coda the monitor and the level of albumin urine which is measured using mouse remember (albumin ) ELISA kit. Data analysis in this research using independent t test. From the results of statistical tests, the effect of SLE on urine albumin levels, the significance level $\rho<0.05(\rho: 0.005)$ and for the effect of SLE on blood pressure the significance level $\rho<0.05$ ( $\rho$ : 0.004) so that it can be concluded that there was Significant influence between the incidence of SLE on urine albumin levels Pregnant SLE model BALB / c mice had higher levels of urine albumin and blood pressure than normal pregnant $B A L B / c$ mice.

Keywords: SLE incidence, urine albumin levels, blood pressure.

\section{PENDAHULUAN}

Lupus eritematosus sistemik atau Systemic Lupus Erythematosus (SLE) merupakan penyakit autoimun multisistem yang berat. Pada keadaan ini tubuh membentuk berbagai jenis antibodi, termasuk antibody terhadap antigen nuklear (ANAs) sehingga menyebabkan kerusakan berbagai organ. Penyakit ini ditandai dengan adanya periode remisi dan episode serangan akut dengan gambaran klinis yang beragam berkaitan dengan berbagai organ yang terlibat. SLE terutama menyerang wanita usia reproduksi. Faktorgenetik, imunologik, hormonal serta lingkungan berperan dalam proses patofisiologi. ${ }^{1,2}$

Patogenesis imunologi pada SLE sebagian besar diakibatkan oleh faktor genetik dan lingkungan. Di bawah pengaruh peningkatan kadar interferon tipe 1 (IFN-1), monosit dalam serum pasien SLE berdiferensiasi menjadi sel-sel dendritik myeloid yang bertugas sebagai Antigen Precenting Cells (APC). Sel-sel ini dapat memfagosit fragmen apoptosis, termasuk fragmen nuklear dan nukleosom. Hal ini dapat menyebabkan aktivasi sel $\mathrm{T}$ dan ekspansi sel B sehingga terbentuk autoantibodi dan menyebabkan kerusakan jaringan melalui pengendapan kompleks antigen antibodi dalam jaringan ${ }^{3}$.

Terganggunya proses apoptosis atau eliminasi partikel dan apoptosis pada SLE menyebabkan terpaparnya antigen intraseluler (yang terdapat dalam sitoplasma) ke ekstrasesluler bersama Mayor Histocompability Complex (MHC) kelas-II sehingga dapat merangsang respon autoimun dan menyebabkan terbentuknya kompleks imun. Dalam keadaan yang normal sel-sel yang mengalami apoptosis akan dieliminasi oleh makrofag pada sistem imun sehingga tidak menginduksi terjadinya respon imun atau inflamasi ${ }^{4}$. Pada pasien SLE, ditemukan gangguan proses klirens dari sel yang terapoptosis sehingga bagian akhir sel terapoptosis yang disebut dengan apoptotic bodies akan ditemukan pada banyak jaringan tubuh pasien SLE $^{5}$

Penyakit SLE yang kebanyakan terjadi pada wanita usia reproduksi seringkali menimbulkan masalah kesehatan terutama pada masa kehamilan yang dapat membahayakan kondisi ibu dan janin. Dilaporkan wanita hamil yang menderita SLE memiliki komplikasi yang buruk terhadap kondisi ibu dan janin. Oleh karena itu penyakit SLE sangat beresiko tinggi pada kehamilan. Risiko kematian ibu hamil yang menderita SLE 20 kali lebih tinggi karena komplikasi yang disebabkan oleh preeklamsi, trombosis, infeksi dan kelainan darah ${ }^{6}$

Kehamilan dengan LES merupakan kehamilan berisiko tinggi, karena dapat membahayakan ibu dan bayi yang dikandungnya. Sekitar $75 \%$ kehamilan mencapai masa kelahiran, walaupun $25 \%$ diantaranya prematur dan $25 \%$ sisanya mengalami keguguran 7 .

Beberapa komplikasi yang bisa terjadi pada kehamilan yaitu kematian janin meningkat 2-3 kali dibandingkan perempuan hamil normal. Bila didapatkan hipertensi dan kelainan ginjal, mortalitas janin menjadi $50 \%$. Pertumbuhan janin juga dapat terhambat sekitar $25 \%$. Sindroma Lupus Eritematosus Neonatal (LEN) merupakan komplikasi kehamilan dengan LES yang mengenai janin dimana sindroma tersebut terdiri atas blok jantung kongenital, lesi 
kutaneus sesaat, kelainan hepar dan berbagai manifestasi sistemik lainnya pada neonatus yang lahir dari seorang ibu yang menderita LES pada saat hamil. $^{8}$

Pada kehamilan normal, laju filtrasi glomerulus meningkat dari $100 \mathrm{ml} /$ menit sampai $150 \mathrm{ml} /$ menit dengan volume intravaskuler yang meningkat. ZsacBNM,.LKJHG[ Pasien SLE yang mengalami kerusakan ginjal dan kardiopulmonar yang membahayakan tidak akan mampu menahan perubahan tersebut dan mungkin dapat mengakibatkan preeklamsia atau kegagalan kardiopulmonar ${ }^{9}$.

Komplikasi kehamilan yang umum terjadi pada wanita dengan SLE menurut Roy et al. (2015) diantaranya tekanan darah tinggi, preeklamsi, eklamsi, perdarahan anterpartum, IUGR, prematuritas, abortus dan bayi lahir mati serta diabetes dalam kehamilan. Komplikasi lainnya yaitu infeksi, tekanan darah tinggi pulmonal, stroke, emboli paru, trombosis vena dan lupus neonatal ${ }^{10 .}$ Masalah yang memperburuk keadaan selama kehamilan adalah terjadinya flare penyakit terutama bila aktivitas penyakit SLE tinggi sebelum hamil. Flare pada kehamilan dilaporkan antara 13\% sampai $68 \%$ lebih tinggi pada penderita SLE yang hamil dibandingkan dengan wanita yang tidak hamil. Jumlahnya meningkat selama kehamilan dan pada masa post partum. Flare penyakit SLE pada kehamilan tergantung dari lamanya masa remisi. Komplikasi yang terjadi pada penderita SLE selama kehamilan ini perlu mendapatkan perhatian yang serius karena keterlambatan diagnosis dan terapi dapat menyebabkan terjadinya kematian ibu dan janin (Kwok et al., 2011) ${ }^{11}$.

\section{METODE PENELITIAN}

Rancangan penelitian yang digunakan dalam penelitian ini adalah true experimental (eksperimental sesungguhnya) dengan pendekatan post test only control group design. Penelitian ini dilaksanakan di Laboratorium Fakultas Kedokteran Universitas Brawijaya. Penelitian ini dilakukan pada Bulan Maret sampai Mei. Variabel bebas dalam penelitian ini adalah Kejadian Sistemik Lupus Eritematosus (SLE) pada mencit BALB/c dengan menilai kadar antibodi ANA pada mencit setelah 12 minggu dilakukan penyuntikan pristan. Variabel terikat dalam penelitian ini adalah kadar albumin urin yang diukur dengan menggunakan Mouse $A L B$ (Albumin) ELISA Kit (Cat No. E-ELM0656) pada hari ke-14 gestasi dan tekanan darah mencit BALB/c yang diukur pada hari ke
14 gestasi menggunakan CODA Non Invasive Blood Pressure System Owner's Manual for CODA Monitor. Penelitian ini menggunakan sampel mencit galur BALB/c bunting yang telah diinjeksi pristan dan diperoleh dari Universitas Islam Negeri Malang. Mencit diberi injeksi pristan $0,5 \mathrm{ml}$ intraperitoneal untuk dijadikan lupus kemudian dibuntingkan sejumlah 20 ekor mencit yang dibagi ke dalam kelompok kontrol dan eksperimen. Analisa Data yang digunakan dalam penelitian ini adalah menggunakan software SPSS 17.0. Data diuji normalitas dan homogenitas, dilanjutkan dengan teknik analisis data yang dilakukan untuk mengetahui perbedaan tekanan darah dan kadar albumin urin pada kedua kelompok dengan menggunakan uji beda independent t test.

\section{HASIL PENELITIAN}

Dari hasil penelitian yang dilakukan pada 20 mencit lupus bunting didapatkan hasil sebagai berikut:

Tabel 1. Pengaruh SLE Terhadap Tekanan Darah dan Kadar Albumin Urin Mencit lupus bunting

\begin{tabular}{|l|l|l|l|r|c|}
\hline & SLE & N & Mean & $\begin{array}{c}\text { Std. } \\
\text { Deviation }\end{array}$ & $\begin{array}{c}\text { P } \\
\text { value }\end{array}$ \\
\hline \multirow{2}{*}{$\begin{array}{l}\text { Albu- } \\
\text { min }\end{array}$} & Tidak & 10 & 871.72 & 508.3 & 0.005 \\
\cline { 2 - 5 } TD & Ya & 10 & 1738.0 & 257.3 & \\
\cline { 2 - 5 } & Tidak & 10 & 69.25 & 5.85 & 0.004 \\
\cline { 2 - 5 } & Ya & 10 & 97.00 & 15.55 & \\
\hline
\end{tabular}

Dari hasil uji statistik menggunakan Independent $t$-test untuk pengaruh kejadian SLE terhadap kadar albumin urin, diperoleh tingkat signifikansi $\rho<0.05 \quad(\rho: 0.005)$ dan untuk pengaruh kejadian SLE terhadap tekanan darah diperoleh tingkat signifikansi $\rho<0.05$ ( $\rho$ : 0.004) sehingga dapat disimpulkan bahwa ada perbedaan kadar albumin urin dan tekanan darah pada mencit $\mathrm{BALB} / \mathrm{c}$ model lupus bunting dengan mencit $\mathrm{BALB} / \mathrm{c}$ model bunting normal.

\section{PEMBAHASAN}

Dari hasil penelitian diketahui bahwa kadar albumin urin pada mencit BALB/c model lupus bunting lebih tinggi (1738.+257) $\mu \mathrm{G} / \mathrm{mL}$ dibandingkan dengan mencit $\mathrm{BALB} / \mathrm{c}$ model bunting normal $(871.72 \pm 508.3) \mu \mathrm{G} / \mathrm{mL}$. Selain itu, tekanan darah pada mencit BALB/c model lupus bunting lebih tinggi $(97 \pm 15.55) \mathrm{mmHg}$ dibandingkan dengan mencit $\mathrm{BALB} / \mathrm{c}$ model bunting normal $(69.25+5.85) \mathrm{mmHg}$

Pada kehamilan dengan SLE ditemukan $50 \%$ kasus flare yang ditemukan pada trimester 
dua dan lebih rendah dari trimestre tiga, hal ini dihubungkan dengan temuan bahwa tingkat hormon estrogen, progesteron, testosteron dan kadar serum DHEAS pada wanita hamil dengan SLE tidak menunjukkan puncak pada trimester ketiga bila dibandingkan dengan wanita hamil sehat, dan hal ini dikaitkan dengan waktu terjadinya flare ${ }^{12}$

Pada penderta lupus, sel B berperan sebagai sel yang memiliki antigen, berikatan dengan sel T pada situs CD 40. Sel T dan sel B saling mempengaruhi, sel $\mathrm{T}$ menghasilkan TNF$\alpha$, interferon- $\gamma$ dan interleukin-10 yang menstimulasi sel B untuk menghasilkan antibodi terhadap antigen yang terikat tersebut. Mekanisme ini diketahui dan membuka peluang untuk pengembangan pengobatan lupus dengan mencari molekul yang menghambat interaksi kedua sel tersebut. Pada proses apoptosis yang normal, sel yang rusak mengeluarkan/ mengekspos antigen untuk dikenali oleh antibodi, yang selama ini terkubur / tertutup oleh kepingan - kepingan sel penutup antigen. Pada penderita lupus hal ini terjadi secara tidak normal pada sel sehat yang yang distimulasi oleh faktor pemicu dari lingkungan, sehingga mengakibatkan pemusnahan sel sejenis oleh produksi antibodi ${ }^{13}$.

Penelitian yang dilakukan oleh Mokbel et al. (2013) terhadap 37 wanita hamil dengan SLE, ditemukan $19,4 \%$ kasus preeklampsia yang dinilai berdasarkan kenaikan tekanan darah dan proteinuria setelah 20 minggu masa gestasi. Dengan menggunakan analisis bivariat, gangguan ginjal ditemukan menjadi prediktor untuk preeklampsia $^{14}$.

Dari penelitian ini didapatkan hasil kadar albumin urin pada kelompok mencit lupus bunting lebih tinggi secara signifikan dibandingkan dengan kelompok mencit bunting normal. Hal ini sejalan dengan hasil penelitian yang dilakukan oleh Satoh et al. (2016) yang menemukan bahwa mencit BALB/c yang diinjeksi oleh pristan secara intraperitoneal tidak hanya menunjukkan peningkatan autoantibodi tetapi juga peningkatan protein urin yang signifikan. Selain itu pemeriksaan menggunakan mikroskop cahaya pada ginjal menunjukkan adanya glomerulonefritis proliferatif segmental, dari mikroskop elektron juga menunjukkan adanya deposit kompleks imun subepitel dan mesangia dan dari hasil imunofluoresen juga menunjukkan adanya penumpukan dari IgM, IgG, dan C3 pada glomerulus ${ }^{15}$.

Keluarnya albumin melalui urin diakibatkan oleh peningkatan permeabilitas di tingkat gromerulus yang menyebabkan protein lolos ke dalam filtrat gromerulus. Konsentrasi protein ini melebihi kemampuan sel-sel tubulus ginjal mereabsopsi dan memprosesnya. Pola protein dalam urin bersifat komplementer dengan pola yang terdapat dalam serum pasien, dengan albumin merupakan protein terbanyak dalam urin 16. Dari hasil penelitian ini diduga peningkatan albumin urin pada mencit lupus bunting diakibatkan oleh adanya gangguan pada tingkat gromerulus ginjal.

Hasil penelitian Postal et al pada 60 pasien SLE anak-anak dibawah 16 tahun didapatkan bahwa terjadi peningkatan TNF- $\alpha$ pada pasien dengan lupus nefritis. Lupus nefritis merupakan prototipe dari kerusakan ginjal yang disebabkan oleh kerusakan imun. Pada lupus nefritis pola kerusakan glomerulus terutama berhubungan dengan dsDNA dan antibodi anti C-1q dan pembentukan kompleks imun. Komplek imun yang mengendap pada permukaan jaringan akan menginduksi respon inflamasi dengan mengaktifkan molekul-molekul adhesi pada endotelium. Hal ini akan mengarah pada perekrutan leukosit proinflamasi. Kerusakan ginjal yang terjadi tersebut disebabkan oleh aktivasi dan kerusakan pada sel-sel glomerulus, infiltrasi makrofag dan sitokin ${ }^{17}$.

\section{KESIMPULAN}

Berdasarkan penelitian yang telah dilakukan, dapat disimpulkan bahwa ada pengaruh yang signifikan antara kejadian SLE terhadap kadar albumin urin dan tekanan darah pada mencit BALB/c model lupus bunting.

\section{DAFTAR PUSTAKA}

1. Sestak AL, Fürnrohr BG, Harley JB, Merrill JT, Namjou B. The genetics of systemic lupus erythematosus and implications for targeted therapy. Ann Rheum Dis. 2011; 70(51):37-43.

2. Bosch X. Systemic lupus erythematosus and the neutrophil. N Engl J Med.2011; 365(8):758-60.

3. Tower, C., Mathen, S., Crocker, I., Bruce, I. N. 2013. Regulatory T cells in systemic lupus erythematosus and pregnancy. American Journal of Reproductive Immunology. 69 (6): 588-595

4. Mok, C.C., Lau, C.S, 2013. Pathogenesis of systemic lupus erythematosus. J Clin Pathol, 56:481-490

5. Shao, W.H., Cohen, P.L. 2011. Disturbances of apoptotic cell clearance in systemic lupus 
erythematosus. Arthritis research and therapy. 13:202.

6. Varghese stephy, Crocker Ian, Bruce N Ian \& Tower Clare. 2011. Systemic Lupus Erythematosus, Regulatory $T$ Cells and Pregnancy.

7. Maisuri T. Sistemik Lupus Eritematosus dalam Kehamilan. Makasar; 2004.

8. Prawirohardjo S. Ilmu kebidanan. Jakarta: PT Bina Pustaka Sarwono Prawirohardjo; 2014.

9. Chaundhary, P., Clowse, E.B. 2012.

Systemic Lupus Erythematosus in the pregnant patient and neonatal Lupus. Cection 10. Connective Tissue Disorders.

10. Roy Sree Joya, Das Pratim Partha \& Datta Anindita. 2010. SLE in Pregnancy. dipublikasikan dalam BSMMU Journal 2010. Diunduh tanggal 18 Agustus 2019.

11. Kwok L.W, Tam L.S, Zhu TY, Leung Y.Y \& Li EK. 2011. Predictors of Maternal and Fetal Outcomes in Pregnancies of Patients with Systemic Lupus Erythematosus. dipublikasikan dalam jurnal permissions 2011. Diunduh tanggal 07 Juli 2019.

12. Doria, A., Ghirardello, A., Iaccarino, L., Zampieri, S., Punzi, L., Tarricone, E. 2004. Pregnancy, cytokines, and disease activity in systemic lupus erythematosus. Arthritis Care \& Research.51(6): 989-995.

13. Evi Roviati. 2012. Systemic Lupus Erithematosus (SLE): Kelainan Autoimun Bawaan yang Langka dan Mekanisme Biokimiawinya. Jurnal Scientiae Educatia Volume 1 edisi 2.

14.Mokbel, A., Geilan, A. M., AboElgheit, S. 2013. Could women with systemic lupus erythematosus (SLE) have successful pregnancy outcomes? Prospective observational study. The Egyptian Rheumatologist, 35(3), 133-139.

15.Satoh, M, Richards, H. B., Shaheen, V. M., Yoshida, H., Shaw, M., Naim, J. O., Reeves, W. H. 2016. Widespread susceptibility among inbred mouse strains to the induction of lupus autoantibodies.
16.Sacher, R.A., McPherson, R.A. 2014. Tinjauan Klinis Hasil Pemeriksaan Laboratorium edisi 11, diterjemahkan oleh Pendit BU; Wulandari D. Protein serum dan plasma. Penerbit Buku Kedokteran EGC, Jakarta. ;311-9.

17. Postal, M., Peliçari, K. O., Sinicato, N. A., Marini, R., Costallat, L. T. L., Appenzeller, S., 2013. Th1/Th2 cytokine profile in childhood-onset systemic lupus erythematosus. Cytokine. 61(3): 785-791. 